\title{
RESÚMENES DE TESIS: DOCTORADO EN FÍSICA
}

\section{Estudio del llenado capilar en estructuras nano-porosas mediante técnicas interferométricas}

\author{
Luisa Guadalupe Cencha \\ Igcencha@gmail.com \\ Director: Dr. Raul Urteaga \\ Co-Director: Dr. Claudio L. A. Berli \\ Lugar de realización: Grupo de Semiconductores Nanoestructurados, Instituto de Física del Litoral (UNL-CONICET) \\ Fecha de defensa: 19 de diciembre de 2018
}

La capilaridad es un fenómeno que ocurre muy a menudo y en muy diversas áreas. Se refiere al proceso mediante el cual un fluido es capaz de ascender por intersticios o canales muy pequeños como consecuencia de su afinidad con el material en cuestión. Los fundamentos subyacentes a este fenómeno se han vuelto muy importantes para el desarrollo de aplicaciones microfluídicas, lo cual ha sido propiciado fundamentalmente por el desarrollo de nuevas y potentes técnicas de micro y nano-fabricación, generando de esta manera un renovado interés por el estudio de los fundamentos y el desarrollo de nuevas aplicaciones.

Entre los tópicos del área que más han llamado la atención de la comunidad científica, se encuentra el estudio de las propiedades de macromoléculas en micro y nano-confinamiento. Este tema, que durante muchos años estuvo limitado al área de recuperación de hidrocarburos, es actualmente de relevancia en numerosas áreas de estudio, entre las que caben destacar la energía, genética, medicina y ciencia de materiales. A pesar de la gran cantidad de trabajos relacionados que surgieron en los últimos años, la explicación de las 
diferencias que existen entre el comportamiento de las macromoléculas al estar fuertemente confinadas o en su estado bulk, es uno de los mayores desafíos que presenta el campo de materia condensada.

Durante el desarrollo de esta Tesis se estudió la dinámica de imbibición capilar de diversos polímeros en matrices porosas de silicio y alúmina anódica. El enfoque consiste en extraer información de los polímeros infiltrados a partir del análisis del cambio de las propiedades ópticas de los medios porosos, debido al ingreso de estos fluidos en los poros. Se utilizaron modelos teóricos conocidos de las propiedades ópticas de materiales compuestos y se trabajó en el desarrollo de modelos fluidodinámicos para describir las dinámicas de imbibición halladas en los diferentes sustratos.

Se analizó la aplicación de un método interferómetrico al estudio de la imbibición capilar de polímeros en membranas nano-porosas. El análisis de esta dinámica de llenado permite estudiar ciertas características del polímero en su estado confinado, como lo es el parámetro de viscosidad. Se validó la aplicabilidad del método a polímeros no entrecruzados, de viscosidades relativamente bajas, para lo cual no existen en la actualidad técnicas que permitan realizar este análisis con las ventajas que aquí se exponen.

Por otro lado, la interacción entre los fundamentos ópticos, fluidodinámicos y de ciencia de materiales, permitió el desarrollo una nueva técnica, basada también en interferometría, pero con mayores capacidades de aplicación. Esto posibilitó el estudio de polímeros en confinamiento en función de la temperatura, expandiendo así el rango de análisis a polímeros de viscosidades muy altas. Este desarrollo también presenta importantes ventajas respecto a los métodos actuales reportados en la literatura y significa sin dudas un aporte importante a la comunidad.

Por otro lado, el estudio de la calidad óptica de las membranas utilizadas, dio lugar a la fabricación de micro cavidades ópticas híbridas de silicio poroso y alúmina porosa, con muy altos factores de calidad. Lo cual es sumamente deseado para el sensado y la detección química y biológica.

\section{Study of the capillary filling in nanoporous structures through interferometric techniques}

The dynamic of capillary imbibition of various polymers in porous silicon and anodic alumina matrices was studied using interferometric techniques. The analysis of the filling dynamics allows one to investigate the polymer viscosity under confinement. The applicability of the technique was validated with unentangled polymers, having relatively low viscosities. To the date, there are no reports on a technique providing the advantages here presented: high temporal-spatial resolution, precise information on the dynamics of imbibition even at the first instants of the process and simplicity of the experimental setup with capability of adaptation to vacuum systems.

The interplay between optics, fluid dynamics and material science fundamentals, allowed the development of a new technique, also based on interferometry, but with greater application capabilities. This 
allowed the study of polymers under confinement as a function of temperature, expanding the applicability to very high viscosity polymers.

In addition, the same fundamentals boosted the invention and development of a micro fabrication technique termed Capillary Imbibition Laser Lithography. The method allows the manufacturing of porous micro channels through the selective imbibition of hot-melt materials in porous membranes, promoted by a localized heating of the material. The common requirement of high specific surface for the microdevices, typical of porous materials, added to other advantages like avoiding bonding steps, makes this development attractive to the microfluidic technology market, which today beats 2000 million dollars, with a sustained growth predicted until 2025. 